\title{
Turismo e museus: uma reflexão empírica sobre a Região Autónoma da Madeira
}

\author{
Diogo José Goes* Luís Filipe Sardinha** \\ Instituto Superior de Administração e Línguas (Portugal)
}

\begin{abstract}
Resumo: O objetivo deste estudo é analisar a evolução dos hóspedes e visitantes dos museus da Região Autónoma da Madeira (RAM), no período 2012 - 2018. Um museu por definição, é uma entidade sem fins lucrativos, ao serviço do desenvolvimento de uma sociedade. Os museus surgem na sociedade com várias finalidades das quais salientam-se: serviço à sociedade, difundir conhecimento, preservar a memória, conservar os objetos de estudo museológico, investigar, divulgar e valorizar cada uma das diferentes tipologias de património cultural e artístico tangível e intangível. A estratégia deste estudo baseou-se na obtenção de informação através da consulta de dados disponíveis nas diversas bases de dados estatísticos existentes. Assim procurou-se fazer a recolha de dados consultando o Instituto Nacional de Estatística e a Direção Regional de Estatística da Madeira. Verificou-se que o número global de visitantes aumentou no período considerado, que sendo provável a relação com o turismo, não foi possível demonstrar uma relação direta entre os fluxos turísticos e a afluência de visitantes nos museus, face aos dados disponíveis. Apurou-se que a realidade museológica da RAM, a par do contexto nacional, está fortemente exposta ao setor do Turismo, colocando em causa a subversão da instituição museológica.
\end{abstract}

Palavras-chave: Cultura; Ilha da Madeira; Museus; Turismo Cultural; Visitantes.

\section{Tourism and museums: an empirical reflection on the Autonomous Region of Madeira}

Abstract: The aim of this study is to analyze the evolution of guests and visitors to the museums of the Autonomous Region of Madeira (RAM), in the period between 2012 - 2018. By definition, a museum is a non-profit entity, serving the development of a society. Museums carry out many services such as spreading knowledge, preserving memory, conserving objects for museum research, and by so doing adding value to both tangible and intangible cultural and artistic heritage. Theresearch was based on existing statistics from the National Statistics Institute and the Regional Statistics Office in Madeira. It was found that the global number of visitors increased over the period considered, probably because of tourism though it was not possible to demonstrate a direct relationship between tourist flows and the influx of visitors to museums, on the basis of the data available. It was found that the museological reality of RAM,is highly exposed to tourism as occurs in the rest of the national context and so may be subverting the institutional characteristics of a museum.

Keywords: Culture; Cultural Tourism; Madeira Island; Museums; Visitors.

\section{Introdução}

A atenção dedicada ao sector da Cultura e à especificidade do universo da museologia está relacionada com os resultados almejados para o Turismo e com a necessidade crescente satisfação da procura, em busca de novas experiências, e sensações, claramente diferenciadoras da oferta turística. Esta procura de sensações, por parte do turismo cultural, leva à consideração de quais as melhores "experiências identitárias" dos lugares visitados.

Instituto Superior de Administração e Línguas (Portugal); E-mail: diogo.costa.goes@gmail.com; https://orcid.org/0000-0003-1996-9789

** Instituto Superior deAdministração e Línguas (Portugal); E-mail: sar_dinha@hotmail.com; https://orcid.org/0000-0002-0920-7599 
O sector museológico português, ao longo dos últimos anos, tem vindo a afirmar-se como um sector dinâmico, mas igualmente heterogéneo, em muitos casos revelando grandes fragilidades (Neves, Santos \& Nunes, 2008).

Neves, Santos \& Nunes (2008), apontando os problemas de operacionalização do sector, consideram que a dificuldade da captação e da qualificação de novos públicos são constrangimentos para a sua afirmação. Disto decorre a dificuldade em implementar uma estratégia de comunicação, e promoção internacional integrada de uma "marca" dos museus, ou do seu património museológico, assistindo à apócope da valorização das coleções e a acervos (Raposo, 2016).

A necessidade de aproximação à realidade identitária e atualização do discurso e das práticas museológicas, museográficas e curatoriais, muitas vezes distam da crescente mutação dos públicos, nomeadamente nas questões das acessibilidades e do uso das novas tecnologias. Torna-se necessário os museus adequarem o discurso museográfico personalizando-o em função das especificidades de cada sujeito-espectador de modo a que cada instituição possa potenciar a melhor experiência ao visitante. Provavelmente, a experiência e a expectativa do turista serão diferentes do residente.

Assim o "público visitante" não pode ser analisado como um sujeito coletivo uniforme, nem como um corpo pluridisciplinar provido de uma pele plurilinguística ou de acesso à informação única, mas sim tendo em conta cada sujeito-espectador, tendo em especificidade cultural e geográfica de cada pessoa, valorizando o carácter humano da mesma, nas suas diferentes motivações, interesses e expectativas (Davis \& Verlag, 2018).

Potenciar o aumento de públicos para os museus somente será possível com uma oferta que coloque a fruição participada, ao nível da experiência sensorial, fazendo corresponder uma progressiva autonomização dos visitantes, que lhes permita leituras inteligíveis dos discursos museográficos, das obras ou objetos expostos.

Com base nestas premissas, procura-se responder à seguinte pergunta de investigação: "Qual a evolução dos hóspedes na Região Autónoma da Madeira (RAM) e dos visitantes nos seus museus?". Definiu-se como objetivo principal refletir sobre os visitantes dos museus situados na RAM, no período entre 2012 e 2018. Como objetivos específicos definiu-se identificar o tipo de visitante dos museus e inferir sobre os resultados.

O presente trabalho, após a introdução, encontra-se estruturado em quatro seç̧ões. No segundo ponto, através de uma revisão bibliográfica pretende-se fazer um enquadramento do tema. No terceiro, apresentamos a metodologia usada e no quarto ponto os resultados e discussão. Em último, apresentamos as conclusões desta investigação.

\section{Revisão da Literatura}

\subsection{Conceito de museu}

Anterior ao próprio conceito de museu estão subjacentes a prática e a conceção de colecionismo. Contudo, a consolidação da lógica do colecionismo e da preocupação pela documentação, inventariação, catalogação e organização das coleções - subjacente ao conceito de museu moderno - tem a sua génese só a partir do final do século XVI e ao longo dos séculos XVII e XVIII, disseminando por toda a Europa a instalação de "Cabinets de Curiosités", Schlosser \& Falguières (2012) na designação francesa ou as "Wunderkammer" na designação germânica, ao gosto humanista, patrocinado, comum à burguesia "de toga”, letrada, em progressiva ascensão e emancipação social, como às cortes europeias iluminadas.

Desde o "gabinete" naturalista de Francesco Calceolari à instalação no Colégio Romano, de objetos da coleção de Alfonso Donnini, à edição de tratado por Frambotto (1656), ou mesmo a obra de Brandolese (1791), demonstra-se a preocupação tratadística sobre o colecionado - depois, sobre o musealizado - ao longo dos séculos seguintes, talvez, tenha vindo a permitir o encontro de uma definição de museu, também enquanto instância de estudo e investigação e não apenas como depósito ou repositório expositivo.

A instituição museológica moderna pública é uma construção ideológica dos liberalismos e republicanismos do século XIX e XX, traduzindo as ideologias estéticas dos novos regimes triunfantes tornando públicas as coleções da aristocracia do Ancien Régime.

Em Portugal, o setor museológico é caracterizado por uma dinâmica própria e heterógena. A definição International Council Of Museums (ICOM) é a referência base para as diferentes definições que se observam. Desde 1946, esta definição tem evoluído, dotando-se de uma maior precisão e abrangência (Neves et al., 2008). 
Etimologicamente, museu (do gr. Mouseion, lat. Museum) significa o templo das Musas que, na mitologia grega, eram divindades femininas, filhas de Zeus e Mnemósine, a personificação da memória. A definição da International Council of Museums Portugal (2015), informa que

"O museu é uma instituição permanente sem fins lucrativos, ao serviço da sociedade e do seu desenvolvimento, aberta ao público, que adquire, conserva, investiga, comunica e expõe o património material e imaterial da humanidade e do seu meio envolvente com fins de educação...”.

Mais recentemente, a ICOM apresenta uma nova proposta de definição contemporizada e adequada às novas especificidades e problemáticas que os museus enfrentam na sociedade em que se inserem, uma sociedade hipermediatizada ou uma "sociedade da sedução" na definição de Gilles Lipovetsky (2019).

Não havendo ainda uma tradução oficial, à presente data deste artigo, o ICOM Portugal (2019) apresenta uma tradução do texto original:

"Os Museus são espaços democratizantes, inclusivos e polifónicos, orientados para o diálogo crítico sobre os passados e os futuros (...) Os museus não têm fins lucrativos. São participativos e transparentes; trabalham em parceria ativa com e para comunidades (...) com o objetivo de contribuir para a dignidade humana e para a justiça social, a igualdade global e o bem-estar planetário.”

Para Carvalho (2003) a conceção moderna de museu e sua prática exige às instituições uma maior componente dinâmica, centrando a projeção do museu no espaço exterior e no envolvimento das comunidades onde se insere.

Se nas décadas de 80 e 90 do século XX a arquitetura de museus de arte, em Portugal, foi marcada por projetos com um sentido completo e durável, no início dos anos 2000 evidencia-se uma nova tendência, baseada no entendimento do museu como uma obra aberta ou "work in progress" (Silva \& Barranha, 2013).

Contudo, entre o museu que se almeja e a realidade da sua inserção no contexto de uma sociedade contemporânea ou "hipermoderna" na definição de Lipovetsky (2019), pode-se empiricamente colocar a hipótese destes museus, presentemente e para futuro, cederem "participar numa estratégia de branding da cidade" conforme Thörn (2011). Os museus confrontam-se com os seguintes desafios: a democratização do acesso à Cultura; a adequação às novas realidades das tecnologias da informação e comunicação com vista à captação de novos públicos. Quanto às necessidades de financiamento, a atratividade turística e a dinamização de atividades de entretenimento e lazer poderão ser uma resposta. Contudo, as atividades de entretenimento nos museus, desfasadas da programação ou da prática museológica, vêm subverter a lógica de preservação de memória e consciência de civilização. Em alguns casos, entronizando ideologias, estéticas, políticas e económicas em vez de possibilitarem a formação integral de novos públicos, promovem o seu contrário. Sobre este aspeto, Lipovetsky $(2019)$ refere que "o mundo dos museus é estruturado pelo princípio da sedução-lazer. Em toda a parte, as cidades em busca de atratividade dotam-se de museus com arquiteturas inovadoras nos antípodas dos antigos museus neoclássicos", traduzindo-se numa dicotomia do fascínio pelo edificado por antítese à fruição dos acervos e coleções. O mesmo autor refere ainda que "O museu era um local de recolhimento (...) agora é um destino turístico de massas, um espaço cultural virado para o consumo visual e hedonista das multidões itinerantes. Já não são museus com objetivos educativos, mas museus atrativos e recreativos".

$\mathrm{O}$ fascínio pelo objeto arquitetónico tem vindo a responder à procura da atratividade turística. Assim, a monumentalidade ou espetacularidade do edificado tem vindo a ganhar relevância em várias geografias. A disseminação transnacional de museus de marca e instituições culturais passam a integrar as estratégias de regeneração urbana orientadas para o lazer e o turismo (Ponzini, Ruoppila \& Jones, 2019). "Ao museu-templo sucedeu o museu-sedução, cuja arquitetura atrai mais o olhar do que as obras e cujas cenografias permitem visitas interativas, distrativas e lúdicas.” Lipovetsky (2019). Vejam-se a título de exemplo os casos de Guggenheim Museum, em Bilbau, e em New York, ou aquele projetado para Abu Dhabi.

Em Portugal continental assiste-se a novos museus, cuja arquitetura é tornada ícone de atração, marcando o território e a paisagem, contribuindo para a mediatização do edificado urbano, a autoria por Mestres da Arquitetura Contemporânea.

O Museu de Arte Contemporânea de Serralves, no Porto, foi da autoria do Arquiteto Álvaro Siza Vieira, prémio Pritzker em 1992 (“Álvaro Siza Vieira | The Pritzker Architecture Prize,” 2020). 
O Museu Nacional dos Coches, em Lisboa, foi instalado em novo edifício, da autoria do arquiteto Paulo Mendes da Rocha, prémio Pritzker em 2006, que, em parceria com o arquiteto Ricardo Bak Gordon, realizou o projeto do novo museu (Coches, 2020; "Paulo Mendes da Rocha | The Pritzker Architecture Prize," 2020).

Note-se que a Resolução do Conselho de Ministros 78/2008 (Diário da República n. ${ }^{\circ}$ 94/2008) considerou a construção de novo Museu Nacional dos Coches enquanto "projeto âncora da reabilitação da zona de Belém-Ajuda" assegurando o seu financiamento, demonstrando uma visão definidora da estratégia cultural de atração turística e do desenvolvimento urbano para cidade de Lisboa. O Museu de Arte, Arquitetura e Tecnologia, desenhado pelo ateliê de arquitetura Amanda Levete Architects, acentua a resposta a essa estratégia, marcando claramente e redefinindo a paisagem, à beira do Tejo (Museu de Arte, 2020).

Estes equipamentos museológicos, tendo sido projetados especificamente para o efeito, absorvem algumas das premissas requeridas para um museu contemporâneo, conseguindo, no entanto, desempenhar um forte papel de atração turística.

No caso da Madeira, merece destaque o premiado Centro das Artes Casa das Mudas, projetado pelo Arquiteto Paulo David, que atualmente acolhe o Museu de Arte Contemporânea da Madeira (Mudas). Este museu foi instalado em 2015, na sequência da trasladação da coleção de arte contemporânea, em depósito na Fortaleza de São Tiago, no Funchal (Madeira, 2020).

As intervenções arquitetónicas dos "novos" museus, a reabilitação de espaços transformando-os e conferindo-lhes um novo uso - o museológico - talvez uso primeiro da "monumentalidade" inscrita num discurso da arquitetura contemporânea, como a melhor estratégia de branding, sobrepondo-se à valorização das próprias coleções e acervos.

Esta dicotomia, quase "neomaneirista", permite ao museu revestir-se de uma pele, que esconde a sua real substância - as coleções, os acervos, a programação. E, provavelmente, basta esta pele para colher os reais impactos, imediatos, no turismo.

"Simultaneamente, estas intervenções tendem a afastar-se do conceito tradicional de reabilitação, transpondo do quotidiano para o campo da arquitetura e da curadoria as noções contemporâneas de reutilização e reciclagem, que pressupõem uma contínua renovação de espaços e de conteúdo" (Silva \& Barranha, 2013).

Os museus hedonistas deixariam de contribuir para consciência e progresso da civilização, passando a ter como principal objetivo a atratividade turística, subvertendo os objetivos do museu contemporâneo, determinando o espaço público e mediático e contribuindo para uma alienação cultural (Goes, 2019).

Armando Coelho, no prefácio do livro "O pincel é uma arma - para a construção de um Museu de Causas" (Santos, 2015) considera que um museu contemporâneo deve aspirar à construção de "um espaço polissémico, de celebração, de criação e expressão pessoal e/ou coletiva em permanente denúncia das patologias do mundo contemporâneo em prol da justiça social: uma heterotopia, outro lugar, como o definiria Michel Foucault."

Por antítese, Muxi (2004) citado por Cruz (2012) constata que, apesar de uma conceção fortemente determinada do ponto de vista da rentabilidade, um museu poderá ser um fator de dinamização económica e atração do potencial turístico. Edifícios históricos, reabilitados e transformados em museus poderão ser catalisadores de regeneração urbana.

Daqui resulta o equívoco, no discurso político e mediático, de que a Cultura tem de satisfazer o interesse das massas e só assim se torna sustentável. Constata-se a aparente impossibilidade de coexistência de uma lógica não lucrativa e filantrópica, definida como princípio cultural orientador, com a interferência das dinâmicas de mercado, como fator de sustentabilidade para as instituições museológicas.

Trata-se, pois, de questões de princípio: a preservação da memória e o acesso ao conhecimento não se coadunam com as lógicas de uma economia de mercado, correndo o risco de substituir a aquisição de um conhecimento aprofundado, por uma lógica de entretenimento fugaz e imediato.

Segundo Goes (2019), "A Cultura do entretenimento tornou-se no melhor e mais hábil instrumento do marketing político e do controlo das massas. E os museus tornaram-se nas hipérboles demagógicas do discurso político e na melhor metáfora do assédio do fruidor/eleitor".

Para Serra \& Carvalho (2010) a atribuição valorativa dos espaços museológicos como lugares hedonistas propícios a práticas de lazer, veio possibilitar que, as instituições museológicas, fossem vistas de um outro modo, ou pelo menos desempenhando um outro papel. Os espaços contíguos aos museus passaram a agregar novas valências: jardins, lojas, cafetarias, contribuindo para a habituação de novos 
públicos. Do ponto de vista da programação e a atualização dos discursos museográficos levaram a que, através de consecutivas exposições temporárias de curta duração, ao invés de permanentes, os visitantes mantenham um constante interesse nas atividades dos museus. Os autores referem que a necessidade de implementação de mecanismos de gestão leva a que o museu assuma uma quota de mercado.

O museu contemporâneo nasce da dicotomia entre as políticas de responsabilidade social de intervir na comunidade onde se insere e na necessidade de justificar a afluência de público para a sua existência ou para seu financiamento, ficando por isso fortemente comprometidos com uma lógica de mercado.

Sobre o conceito de museu, para futuro, pode-se considerar como corpo da sua missão e objetivos, a promoção da inclusão social. Sobre este propósito fará sentido afirmar que todos os museus são de facto museus de causas, ou como na proposta de Santos (2015) para a criação de uma instituição museológica "Paleta Contemporânea - Museus de Causas" que possa não ser apenas repositório, mas se afirme também como verdadeiro Centro Cultural (...) e seja protagonista no próprio desenvolvimento dos mais diversos canais de divulgação de todo o processo criativo (Santos, 2015). O mesmo autor aponta que será desejável "estabelecer um estreito diálogo entre o público e neste caso especial, com o mais jovem, tentando assim contribuir para uma maior sensibilização da comunidade juvenil, para o gosto e para a prática das artes plásticas."

De acordo com Goes (2019), os museus do futuro, deverão ser "mais inclusivos e politicamente comprometidos, não sistematizando hierarquias historiográficas" e criando novas narrativas em diálogo com as comunidades, despoletando nelas o interesse no património museológico.

A Lei Quadro dos Museus Portugueses, Lei n. ${ }^{\circ}$ 47/2004, de 19 de agosto, embora assuma basear-se no conhecimento da realidade portuguesa, está conforme as orientações internacionais e apresenta uma definição de museu muito próxima da veiculada pelo ICOM.

Segundo Monge (2018), "a opinião consensual é a de que a Lei-Quadro, necessitando embora de adaptação a novas realidades, designadamente com a criação da Direção-Geral do Património Cultural (DGPC), configura o enquadramento desejável para os museus portugueses.”. A mesma autora ainda refere que o ICOM Portugal "(...) assume a preocupação com o desinvestimento na qualificação dos museus (...).” Promover a implementação da totalidade das disposições previstas na Lei-Quadro parece ser a melhor forma de garantir que qualquer projeto de descentralização de competências na área dos museus significará uma opção propiciadora de um tecido museológico qualificado e empenhado na construção de uma sociedade melhor e mais justa.

Considere-se ainda legislação aplicável sobre a matéria em estudo, demonstrando a vocação das instituições museológicas, nomeadamente na criação de novos públicos locais, jovens, através da gratuitidade do acesso aos bens culturais. Como exemplo, veja-se a iniciativa "Cultura para todos!", conforme o despacho n. ${ }^{\circ}$ 2880/2020 (Diário da República n. ${ }^{\circ}$ 45/2020, Série II de 2020-03-04, 2020).

A Constituição da República Portuguesa (2005) consagra no seu artigo 9. ${ }^{\circ}$, alíneas d) e e), como tarefa fundamental do Estado: promover a efetivação "dos direitos culturais" e "proteger e valorizar o património cultural”, respetivamente, também nos artigos $42 .^{\circ}$ e $43 .^{\circ}$, o princípio da liberdade de criação cultural e de ensinar e aprender.

\subsection{Tipologias de Museu}

Os museus apresentam uma tipologia heterogénea e podem ser classificados de acordo com diferentes critérios. O Instituto Nacional de Estatística (2009) identifica diferentes tipos de museus, os quais estão resumidamente apresentados na tabela 1.

\section{Tabela 1: Tipologia de Museus}

Segundo o Instituto Nacional de Estatística (2009) existem 7 tipologias principais de museus, a saber:

Museu de Arte (consagrado às belas-artes, às aplicadas e às performativas); Museu de História (ilustra um determinado tema, personalidade ou momento histórico); Museu de Ciências Naturais e História Natural (consagrado a uma ou mais disciplinas das ciências naturais); Museu de Ciência e Técnica (consagrado às ciências exatas ou técnicas); Museu de Etnografia e de Antropologia (relacionados com a cultura, estruturas sociais, crenças, costumes e tradições); Museus de Territórios (representativas de um território específico) e Museus Mistos e Pluridisciplinares (com coleções heterogéneas, não identificadas por um tema em particular) e outros. 
As tipologias apresentadas fazem uma triagem de acordo com a natureza das coleções dominantes. Outra categorização distingue os museus por dimensão (museus nacionais, museus regionais, museus locais, etc.); tutela (museus privados, museus municipais, museus mistos, etc.); unidades (polinucleados e núcleos, etc.), e relação com as comunidades (ecomuseus, museus de região, museus de comunidade, etc.), entre outras (Marques, 2014; Raposo, 2010).

\subsection{Museus na Região Autónoma da Madeira}

Os dados disponibilizados pelo Instituto Nacional de Estatística (2020) indicam que no período de 2012 a 2018, o número de museus tem crescido. Em 2018 o número de museus em Portugal ascendeu a 431.

Relativamente à Região Autónoma da Madeira, verifica-se que o seu crescimento apesar de positivo não foi uniforme (Tabela 2).

Tabela 2: Evolução do Número de museus na RAM por ano

\begin{tabular}{|c|c|c|c|c|c|c|c|}
\hline Localização & 2012 & 2013 & 2014 & 2015 & 2016 & 2017 & 2018 \\
\hline $\begin{array}{l}\text { Região } \\
\text { Autónoma da } \\
\text { Madeira }\end{array}$ & 15 & 17 & 19 & 16 & 16 & 19 & 18 \\
\hline Calheta & 0 & 0 & 0 & 0 & 0 & 1 & 1 \\
\hline Câmara de lobos & 0 & 0 & 0 & 0 & 0 & 0 & 0 \\
\hline Funchal & 10 & 12 & 13 & 10 & 11 & 12 & 12 \\
\hline Machico & 2 & 2 & 2 & 2 & 2 & 2 & 2 \\
\hline Ponta do Sol & 0 & 0 & 0 & 0 & 0 & 0 & 0 \\
\hline Porto Moniz & 1 & 1 & 1 & 1 & 1 & 1 & 0 \\
\hline Porto Santo & 0 & 0 & 1 & 1 & 1 & 1 & 1 \\
\hline Ribeira Brava & 1 & 1 & 1 & 1 & 1 & 1 & 1 \\
\hline Santa Cruz & 0 & 0 & 0 & 0 & 0 & 0 & 0 \\
\hline Santana & 1 & 1 & 1 & 1 & 0 & 1 & 1 \\
\hline São Vicente & 0 & 0 & 0 & 0 & 0 & 0 & 0 \\
\hline
\end{tabular}

Fonte: Adaptado de Instituto Nacional de Estatística (2020)

Em 2018, a Região Autónoma da Madeira apresentava 18 museus, sendo que um está localizado no Porto Santo. O concelho que apresenta maior número de museus é o do Funchal. Já os concelhos de São Vicente, Santa Cruz, Ponta do Sol, Porto Moniz e Câmara de Lobos não apresentam nenhum museu.

\subsection{Turismo}

O turismo em Portugal tem sido um impulsionador da economia. Portugal tem um plano definido até 2027. Neste documento, "Estratégia Turismo 2027 - Liderar o Turismo do futuro", é feita uma análise da evolução do turismo em Portugal da qual se destaca: em 2002, o número de hóspedes em estabelecimentos hoteleiros portugueses era praticamente metade do que se registou em 2017 . À exceção de 2009, a tendência é de crescimento; desde 2010, o número de dormidas em Portugal tem crescido, em 2017 apresentou um aumento de quase quatro milhões de dormidas. Os estrangeiros representaram sete em cada dez dormidas; em 2017 a receita por quarto disponível é de 50,2 €; Reino Unido, Alemanha, Espanha e França são os países que mais visitam Portugal.

Em 2018, os portugueses efetuaram 22,1 milhões de deslocações turísticas, das quais 19,6 milhões dentro do território nacional. As dormidas em Portugal totalizaram 69,6 milhões e no estrangeiro ascenderam a 18,3 milhões, ascendendo no global a 87,8 milhões. Os portugueses gastaram, em média, $121,5 €$ em cada viagem em Portugal e 525,7€ no estrangeiro Mello (2019).

Ao nível da Região Autónoma da Madeira "o Sector do Turismo desempenha um papel fundamental na economia da RAM, envolvendo diversos setores da atividade económica, incluindo hotelaria, 
operadores turísticos, agências de viagem, restauração, (...)" (Associação Comercial e Industrial do Funchal \& KPMG, 2014).

Em 2015, o Turismo era responsável por 15\% do emprego regional e com um contributo para o PIB da RAM que ronda os 25\%. Cerca de $84 \%$ dos passageiros do Aeroporto da Madeira residem fora do Arquipélago. Destes destacam-se os Portugueses, Alemães, Ingleses e Franceses (Secretaria Regional da Economia Turismo e Cultura, 2016). Verifica-se assim que o setor do turismo é o principal motor e alavanca da economia regional.

Em 2017 é aprovado o Plano para o Ordenamento do Território na Região Autónoma da Madeira (POTRAM) (Decreto Legislativo Regional n ${ }^{\circ}$ 15/2017/M, 2017). Neste documento estão patentes as principais linhas orientadoras e metas para o futuro em relação ao desenvolvimento sustentável do setor, no qual se salientam os seguintes objetivos: "3) Reforçar a formatação dos produtos de nicho, tendo em vista aumentar a atração dos públicos turísticos (...) 5) Otimizar a oferta secundária numa lógica de articulação em rede, aproveitando o facto de a Madeira apresentar hoje uma oferta secundária mais rica e diversificada, seja em termos culturais (...) 6) Aumentar o peso da Cultura no ordenamento estratégico do Turismo pelo facto de a oferta cultural da RAM ser rica e diversificada ao nível das atividades, dos equipamentos e dos agentes.”. A visão defendida para o futuro assenta num novo paradigma que assume a qualificação e consolidação da oferta, o reforço da notoriedade e atratividade do destino e a melhoria dos seus indicadores de desempenho, como prioridades.

Em 2018, a RAM, ao nível da oferta turística disponível no conjunto dos meios de alojamento, abrangendo a hotelaria, turismo no espaço rural e alojamento local (excluindo o alojamento local abaixo das 10 camas), apresentava 34399 camas, cuja a oferta se encontra concentrada em 16284 quarto. O número de dormidas no alojamento turístico aproximou-se dos 8,4 milhões, sendo 938,3 mil provenientes de residentes em Portugal. Os principais mercados emissores no alojamento turístico coletivo em 2018 foram Alemanha (28,2\%) e Reino Unido (26,6\%). A receita por quarto disponível (RevPAR), em 2018, na RAM, foi de 47,47 € (Direção Regional de Estatística da Madeira, 2019).

Num contexto em que o Turismo mundial cresce acima dos 3\% e vários indicadores no território continental português, registam sucessivos aumentos da procura turística, 7,7\%, face a 2017 e um valor acrescentado bruto (VAB) gerado pelo setor, que cresceu 8\% em 2018. O turismo cresceu em Portugal mais $4,1 \%$ do que o resto da economia em 2018. Na Região Autónoma da Madeira tem se vindo a verificar sucessivos e acentuados decréscimos contrariando a tendência nacional em períodos homólogos, exceto em 2017. Em 2019, foram mais de 214 mil as dormidas perdidas em 11 meses, segundo os dados disponibilizados, que quando comparadas com o período homólogo de 2018, demonstram uma acentuada diminuição dos proveitos totais, rondando $5 \%$ de perdas (Goes, 2020).

\subsection{Turismo Cultural e os Museus}

Segundo Gonçalves (2009b) no atual contexto da sociedade global os conceitos de museus e turismo são relacionáveis ou até interdependentes na medida em que podem potenciar a atração do público turista, contribuindo para o debate do papel dos equipamentos culturais numa sociedade da informação e do lazer.

A mesma autora, considera a possibilidade dos museus se constituírem como fator diferenciador da oferta e da atração turística e também dinamizadores do tecido económico e cultural. Sobre este aspeto, se os museus constituem ou não, atratividade para o turismo, ou se deles beneficiam, com o aumento de número de visitantes, pode-se constatar que no caso Português, desde 2012, existe uma dissonância entre um tendencial crescimento do turismo a nível internacional e o baixo número de visitantes a nível nacional, replicando-se o mesmo "sintoma" às regiões autónomas.

Para a captação de novos públicos aos museus e maximização do seu potencial, importa que hajam "abordagens próximas do território e dos seus recursos" que ao possibilitarem a inclusão das comunidades locais, nas quais os museus estão inseridos, colaborando desde a sua conceção e participando na programação, permitem que o espaço se constitua "como um estímulo à diversidade cultural, assim como, a proximidade espacial entre vários recursos turísticos, culturais e patrimoniais podem potenciar a constituição de clusters nas áreas do turismo e do lazer, afirmando-se como ofertas diferenciadoras dos destinos turísticos. Estas aglomerações de recursos também são boas oportunidades para a construção de economias nas operações destes espaços e equipamentos, que, por sua vez, trazem ganhos de atratividade para o turismo." (Gonçalves, 2009b).

De acordo com Luís Raposo (2016), constatava que, segundo resultados de um inquérito de 2012 que lamentava "a ausência de Portugal da lista dos 100 museus de arte mais visitados do Mundo. 
Situação mais agravada ainda porque Lisboa nem sequer figurava também na lista das exposições com mais 1000 visitantes/dia (contrariamente ao Porto, através de cinco exposições realizadas em Serralves).”. Verificou-se que a retoma económica e o crescimento do turismo, poderão ter contribuído para uma evolução: "Em 2015, Portugal já surge representado na lista dos 100 museus, com um museu lisboeta (Museu Berardo). E, com onze exposições, todas no Porto e em Serralves" (Raposo, 2016). $\mathrm{O}$ mesmo autor ainda refere que, contudo, "num contexto em que o turismo estrangeiro conhece uma verdadeira explosão, com taxas anuais superiores a dois dígitos, refletidas em alguns museus (...)" continuam as dificuldades sistémicas das estruturas de decisão. "Ninguém ousa atuar audaciosamente (...) criando no imediato uma task force para pensar pacote de museus e exposições a incluir na oferta turística de uma capital". Acrescenta ainda a sua crítica, quer ao plano da promoção, quer no plano dos dados disponíveis.

"As vistas curtas não são apenas estreitas no plano da promoção dos nossos museus junto dos circuitos internacionais. São também, e antes de tudo, junto dos cidadãos nacionais. No caso português escasseiam os dados e o inquérito referido abrange um universo de museus muito restrito".

Uma plausível razão para este efeito poderá ser a falta de divulgação internacional dos mesmos, e o facto de alguns museus manterem ainda, exposições permanentes sem rotatividade do exposto e/ou exposições de longa duração, com pouco estímulo para o retorno do visitante - o que subverte a lógico da conceção de "museu contemporâneo".

Refere-se que, em 2012, a influência do público nacional, no considerado baixo número de visitantes, poderá refletir o estado de crise financeira e económica em Portugal, estando intervencionado externamente. Poderemos extrapolar os impactos na Região Autónoma da Madeira. A crise poderá ter originado uma quebra de confiança dos consumidores, nomeadamente os consumidores culturais, contudo tal não vem justificar o baixo número de visitantes à data e o exponencial de crescimento subvalorizado (Instituto Nacional de Estatística, 2015).

Gonçalves (2009a) considera a partir de Aalst and Boogaarts (2002) que os clusters baseados nos museus se constituem como estratégias de sucesso e que, quase todas as grandes cidades, apostaram nos museus como forma de regeneração dos seus centros urbanos e de revitalização das suas economias. Demonstrou-se que a concentração dos museus traz vantagens, nomeadamente no estabelecimento de sinergias, partilha de meios e infraestruturas e na melhoria das acessibilidades possibilitando a abrangência de diferentes públicos, especificamente os turistas.

A cultura tem ganho uma dimensão estratégica e os museus, não raramente, promovem atividades com potencial de atração turística que estão na base de economias locais e regionais. Atualmente, os turistas representam uma parte importante das visitas aos museus, tornando-se, em alguns casos, uma percentagem expressiva do seu público (Gonçalves, 2009a).

A possibilidade de estabelecer relações/diálogos entre os museus e o mercado turístico, visa fundamentalmente a sua inserção e viabilização "como atrativos turísticos, através da sua transformação em produtos turísticos-culturais" dando perceção de que "para a concretização dos museus como roteiros de destinos culturais é necessário identificar qual o tipo/perfil de turista que os visitam; turista este identificado pela literatura como "turista cultural" (Morais, 2013). Por essa razão, os museus deverão investir na identificação dos públicos e investigação das especificidades dos seus interesses, origens e caraterísticas, para melhor direcionar a sua promoção e estratégias de comunicação. Acrescenta que, o turismo constitui uma oportunidade para garantir a sustentabilidade dos museus, pela importância de estes serem os garantes da transmissão de conhecimento e desenvolvimento de valores universais e tolerância, pela identidade do representado. Gonçalves (2009b) aponta também como principais pressupostos os factos decorrentes da mudança de paradigma do turismo, onde se substituiu o produto de destino comercial pela oferta de uma experiência que não se dissocia da identidade cultural do território visitado e experienciado. Por essa razão, tornar-se-á cada vez mais difícil não relacionar as práticas turísticas com as práticas culturais e com estas surgir novos fenómenos de sincretismo cultural. Daqui emerge a necessidade de preservação do património edificado e artístico, material e imaterial confirmando autenticidade da experiência tida pelo turista visitante.

"O reconhecimento da importância da sustentabilidade cultural já foi apreendido pelo turismo cultural e os agentes do turismo estão hoje conscientes que o futuro da indústria turística depende da proteção e preservação dos recursos ambientais, patrimoniais e culturais de cada região" (Gonçalves, 2009b). 
Se por um lado é possível deduzir impactos económicos positivos nas estratégias adotadas, de transformação dos centros históricos, em "clusters museológicos" também é possível notar que os habitantes desses mesmos centros, poderão ter de coexistir com um novo antagonismo originado pelo fenómeno turístico: em vez (da arte, dos clusters culturais e das instituições museológicas) promoverem a inclusão social, submetem a um novo julgo económico aqueles que habitam aqueles lugares, instituindo novos "não-lugares" nas cidades. Os Museus como o espaço público que os envolve, e no qual estão edificados, poderão potenciar a não habitabilidade das cidades e com isso torná-las "não-lugares", na definição de Marc Augé, lugares transitórios, de passagem. Daqui decorre também o perigo das cidades ao se tornarem museus ao ar livre, perderem a sua essência de lugar habitado e de não cumprirem a sua missão e se tornarem num lugar contemplativo apenas do sublime (Goes, 2019).

Como refere Queiró (2017), "O que faz Portugal permanecer é a história da população que sente como sua, uma cultura antiga e enraizada, mesmo que também modificada e adaptada. E, sobretudo um sentido de pertença, uma vontade assumida de existência como comunidade.”. É válido extrapolar que este sentimento de pertença e identificação cultural, esteja intimamente ligado aos papéis das instituições museológicas, como pelas instituições de ensino. É de destacar a possibilidade do estabelecimento de sinergias entre ambas instituições, principalmente no foro da investigação científica, na conservação e preservação e numa vertente educativa.

Russo e Van de Borg (2002), citados por Serra \& Carvalho (2010), afirmam que sob o vetor de análise do turismo, o património deve ser explorado para a obtenção de lucro, nas mais diversas atividades e situações. A relação entre turismo e património deve ser bem ponderada, na medida em que nem sempre o desenvolvimento turístico é compatível com a conservação patrimonial. Porém, acontece que em muitos locais são os recursos financeiros obtidos da exploração turística do património que viabilizam orçamentos de preservação e salvaguarda deste.

A tentativa de atrair novos públicos, com diferentes especificidades geográficas e culturais, na perspetiva de divulgação e partilha de conhecimento poderá ser uma mais valia. $\mathrm{Na}$ ótica de mercado poderá responder às suas necessidades, invertendo a função de museu. Assim, museus e turismo olham o património de diferentes ângulos: os primeiros procuram a sua preservação e conservação por meio de processos e estudos interpretativos, numa vertente educativa; o segundo tem uma visão mais exploradora do património, visando a criação de valor económico, sendo que sua sustentabilidade varia consoante estejam orientadas as práticas turísticas e com as políticas de salvaguarda patrimonial em vigor no local (Serra \& Carvalho, 2010).

Clara Camacho (ICOM Portugal), a propósito da palestra «O Método como Mensagem: Participação e Valor das Coleções» ministrada por Peter Van Mensch, destaca a importância de "um envolvimento ativo da comunidade nas decisões dos museus, designadamente quanto à relevância das coleções, conectando-as com o mundo exterior" (Portugal, 2018). A melhor forma dos museus comunicarem a sua mensagem é através da participação das comunidades, conseguindo que estas reconheçam a importância da preservação, conservação e divulgação do acervo neles existentes.

\subsection{Museus em rede e fluxos turísticos}

Lira (2002) citado por Serra \& Carvalho (2010), defende que integração de museus em redes e roteiros turísticos traz benefícios quer para o turismo, quer para o museu, pois a articulação entre ambos fará com que os turistas visitem mais espaços uma vez interligados. Será de notar a inexistência de um roteiro entre museus na Região Autónoma da Madeira (RAM) - existentes são alguns roteiros ou percursos sobre património, nomeadamente a arquitetónico e religioso, ou de arte contemporânea, de iniciativa privada - sendo a tarefa complexa pela dificuldade de trabalho em redes intermunicipais ou entre os próprios museus de mesmas tutelas, salvo exceções, de alguns projetos pontuais.

Considere-se o exemplo no território continental, o projeto «Rede de Museus e Equipamentos Culturais de Évora», apresentado por Filipe Barata (Universidade de Évora) com o objetivo de envolver "a gestão dos fluxos turísticos e a maximização do retorno económico.". Contudo a rede proposta "não tem preocupações nas áreas dos conteúdos e da programação, da educação patrimonial e ligação à comunidade e, sobretudo, dos recursos humanos" (Monge, 2018) e poderá levar a colocar como hipótese, a subversão da lógica do próprio museu.

A conceção de redes ou roteiros que não tenham, em conta a envolvência das comunidades poderá constituir razão para um maior afastamento das populações locais, porque o papel do museu, dista da vocação de um centro cultural, temático, interpretativo ou de uma galeria, desfasado de uma lógica mais "comercial". 
O visitante do museu é também um turista cultural, uma vez que procura contactar com outras culturas, conhecer outros povos e tradições, para enriquecer a sua própria cultura (Serra \& Carvalho, 2010). Os mesmos autores afirmam que no contexto internacional dos mercados emissores, o turista, com recurso às tecnologias de informação digital, "planeia autonomamente as suas deslocações, tendo um total controlo sobre a administração do seu tempo livre" tentando fugir à massificação nos destinos turísticos, excetuando os locais icónicos da História e Património mundial.

No caso do destino Madeira, empiricamente, sugere-se que, na atualidade, o fator museus, as suas coleções e acervos, só por si não constituem fator preferencial para atração turística, quer porque não existem dados que o possam verificar, quer porque não existe um real dimensionamento dos Museus na Madeira para essa própria promoção.

Outro aspeto que importa realçar é o facto de um museu "para turistas" provavelmente exclui aqueles que habitam em seu redor. Os museus que não potenciem a inclusão social, poderão originar a exclusão, das pessoas que com eles não se identificam (Moreno-Mendoza, Santana-Talavera, \& Boza-Chirino, 2020).

A relação com o turismo e museologia, nos demais contextos, "trouxe mutações em ambas as partes, sendo que são mais notórias as mudanças nos museus, que se adaptaram para receber a atividade turística”. Pesa o facto de o turismo deixar uma pegada ecológica, acentuada, sem que os proveitos reais se traduzam numa real preservação do património edificado e da conservação dos acervos e coleções, justificando-se para isso um relacionamento que potencie a sustentabilidade não só económica de ambos sectores, como a cultural e patrimonial (Serra \& Carvalho, 2010).

\section{Metodologia}

\subsection{Dados e Métodos}

De acordo com Gil (2017), a pesquisa descritiva tem como principal objetivo descrever características de determinada população ou fenómeno ou o estabelecimento entre relações entre variáveis. Tem o objetivo de "descrever as características de determinada população ou fenómeno ou o estabelecimento de relações entre variáveis" (Prodanov \& Freitas, 2013).

Segundo Barañano (2008), dados secundários

“... são dados previamente recolhidos por outros investigadores ou instituições e com objetivos diferentes dos posteriores utilizados. A utilização de dados secundários é uma ferramenta metodológica comum em Gestão e apresenta algumas vantagens, tais como: análise de amostras grandes e são mais baratos que a criação de dados primários (Barañano, 2008; Lakatos \& Marconi, 2017; Prodanov \& Freitas, 2013).

A estratégia deste estudo baseou-se na obtenção de informação através da consulta de dados disponíveis nas diversas bases de dados estatísticos existentes. Assim procurou-se fazer a recolha de dados consultando o Instituto Nacional de Estatística (INE) e a Direção Regional de Estatística da Madeira (DREM). Os dados foram levantados em janeiro de 2020. O tratamento estatístico foi realizado recorrendo do Microsoft Office Excel.

\section{Resultados}

Tendo em conta a natureza do estudo, optou-se por apresentar e analisar os dados e depois fazer a discussão e conclusão em simultâneo. Para o cálculo das estatísticas descritivas e para os tratamentos estatísticos recorreu-se ao Microsoft Office Excel. 
Figura 1: Hóspedes entrados nos estabelecimentos de alojamento turístico por país de residência habitual

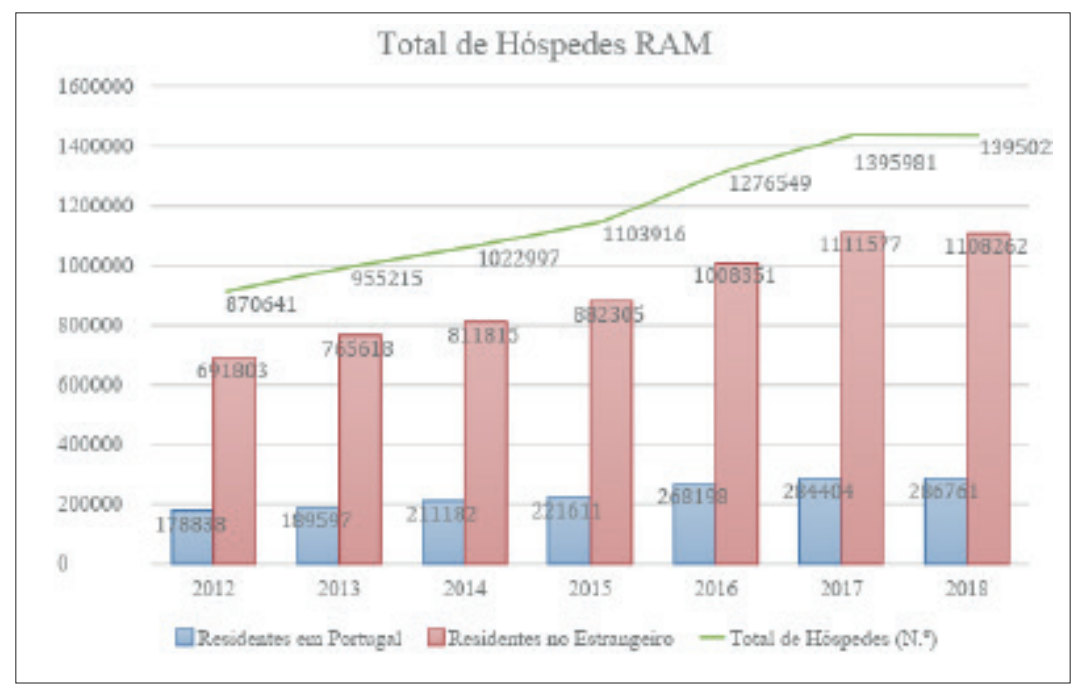

Fonte: Direção Regional de Estatística da Madeira (2019b)

No período considerado, 2012 a 2018, verifica-se um aumento constante do número de hóspedes, com ligeira atenuação entre 2017 e 2018 passando de 1395981 para 1395023 . De 2015 para 2016 existiu um aumento do número de hóspedes maior que nos outros anos passando de 1103916 para 1273 549 traduzindo-se num aumento de 15\%. Relativamente à sua nacionalidade, os hóspedes residentes em Portugal têm aumentado de uma forma constante. Já os hóspedes estrangeiros têm aumentado, no período considerado e com maior expressão em comparação aos hóspedes residentes em Portugal.

\subsection{Visitantes de Museus}

Figura 2: Evolução do número de visitantes museus da RAM

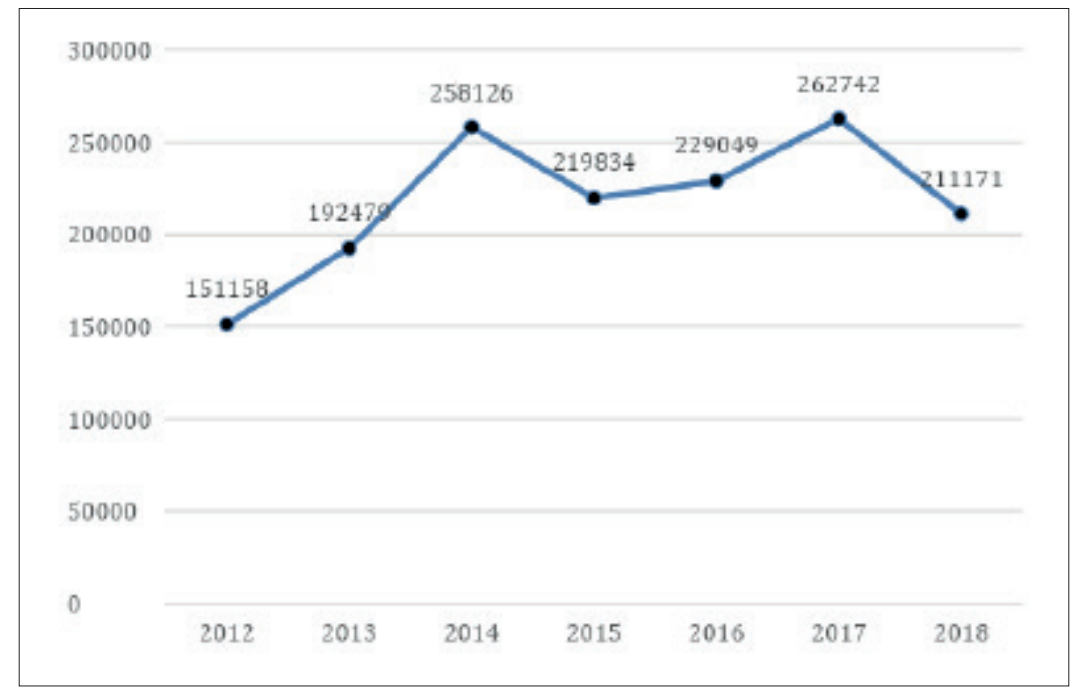

Fonte: Instituto Nacional de Estatística (2019) 
Tabela 3: Visitantes de museus por localização na RAM por ano

\begin{tabular}{|l|c|c|c|c|c|c|c|}
\hline \multicolumn{1}{|c|}{$\begin{array}{c}\text { Visitantes } \\
\text { (N. }{ }^{\mathbf{9}}\end{array}$} & $\mathbf{2 0 1 2}$ & $\mathbf{2 0 1 3}$ & $\mathbf{2 0 1 4}$ & $\mathbf{2 0 1 5}$ & $\mathbf{2 0 1 6}$ & $\mathbf{2 0 1 7}$ & $\mathbf{2 0 1 8}$ \\
\hline $\begin{array}{l}\text { Regiáa } \\
\text { Autónoma da } \\
\text { Madeira }\end{array}$ & 151158 & 192479 & 258126 & 219834 & 229049 & 262742 & 211171 \\
\hline Calheta & 0 & 0 & 0 & 0 & 0 & 16352 & 20206 \\
\hline $\begin{array}{l}\text { Câmara de } \\
\text { Lobos }\end{array}$ & 0 & 0 & 0 & 0 & 0 & 0 & 0 \\
\hline Funchal & Confidencial & 144906 & 204741 & 162191 & 161392 & 176398 & 128522 \\
\hline Machico & 17825 & 21699 & Confidencial & 24285 & 29871 & 32158 & 33788 \\
\hline Ponta do Sol & 0 & 0 & 0 & 0 & 0 & 0 & 0 \\
\hline Porto Moniz & Confidencial & 3947 & Confidencial & 9782 & 10017 & 8320 & 0 \\
\hline Porto Santo & 0 & 0 & Confidencial & 15001 & 17360 & 16754 & 17499 \\
\hline $\begin{array}{l}\text { Ribeira } \\
\text { Brava }\end{array}$ & 12617 & Confidencial & Confidencial & Confidencial & 10409 & 9960 & Confidencial \\
\hline Santa Cruz & 0 & 0 & 0 & 0 & 0 & 0 & 0 \\
\hline Santana & Confidencial & Confidencial & Confidencial & Confidencial & 0 & 2800 & Confidencial \\
\hline São Vicente & 0 & 0 & 0 & 0 & 0 & 0 & 0 \\
\hline
\end{tabular}

Fonte: Instituto Nacional de Estatística (2020)

Com base nos dados apresentados pelo INE foi possível verificar um aumento, não constante, do número de visitantes nos museus situados na Região Autónoma da Madeira (RAM), no período de 2012 a 2018 (figura 2). Foi possível analisar que o ano de 2014 apresentou quase tantos visitantes (258 126) como o ano de 2017 (262 742).

No ano de 2018, os 18 museus na RAM que cumpriram os 5 critérios de elegibilidade de apuramento do Inquérito aos Museus, registaram cerca de 211 171, -19,63\% que em 2017 (262 742).

Numa perspetiva de análise por concelhos, no Funchal verifica-se que 2014 foi o ano que apresentou maior número de visitantes de museus. Os concelhos de Câmara de Lobos, Ponta do Sol, Santa Cruz e São Vicente não apresentaram registos de visitantes. Os concelhos de Machico, Porto Moniz, Porto Santo, Ribeira Brava e Santana em alguns períodos apresentaram os dados como confidenciais (tabela 3).

\subsection{Visitantes Estrangeiros (VE) de Museus}

Ao nível dos visitantes estrangeiros é possível constatar que o seu crescimento, apesar de positivo não foi constante (figura 3). O período que apresentou um maior crescimento do número de visitantes foi de 2015 para 2016, passando de 108569 para 138 046, o que representa um aumento de 27\%.

Do total de visitantes registados em 2018, 63,2\% eram estrangeiros (133 448) (figura 4) e 13,6\% eram visitantes inseridos em grupos escolares (figura 5). 
Figura 3: Número de visitantes estrangeiros dos museus

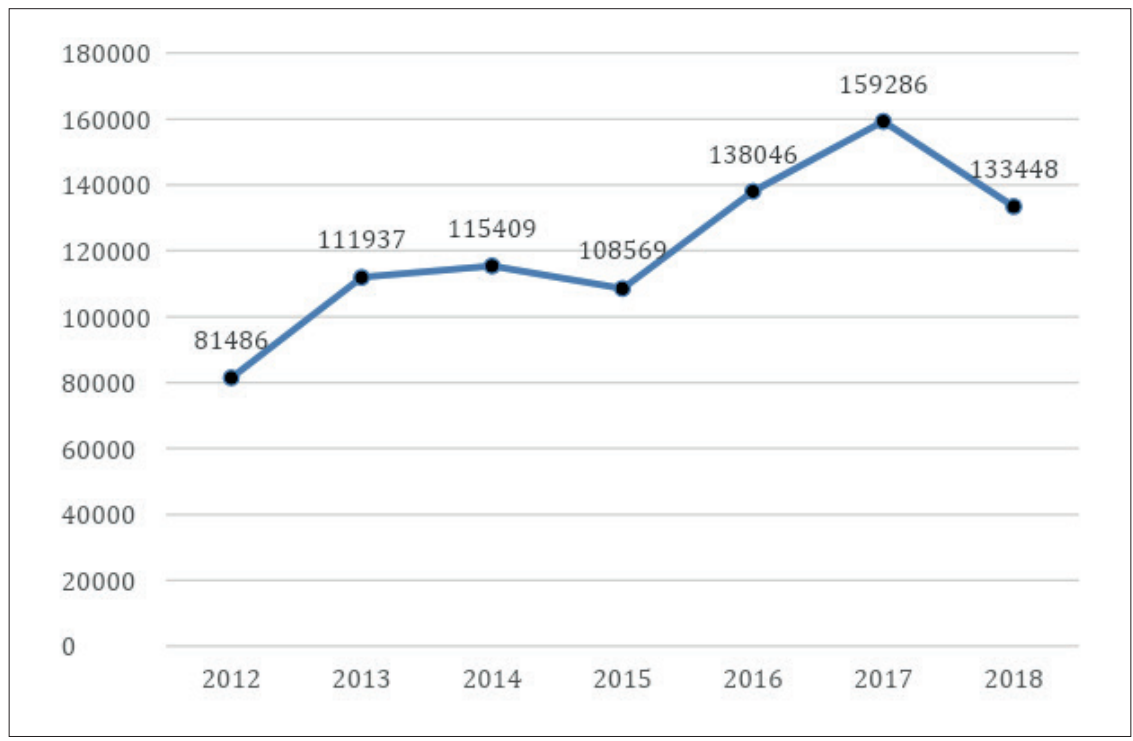

Fonte: Instituto Nacional de Estatística (2019)

Numa análise comparativa entre VE e o número total de visitantes dos museus, verifica-se que durante o ano de 2012 e 2013 o número de visitantes totais aumentou bem como o número de visitantes estrangeiros. Durante o período de 2013 a 2015, apesar do número de visitantes totais ter aumentando o número de VE não acompanhou essa tendência. A partir do ano de 2015 até ao de 2017 ambos aumentaram de forma gradual, invertendo o padrão em 2018 (figura 4).

Figura 4: Total de visitantes dos museus vs Visitantes Estrangeiros na RAM

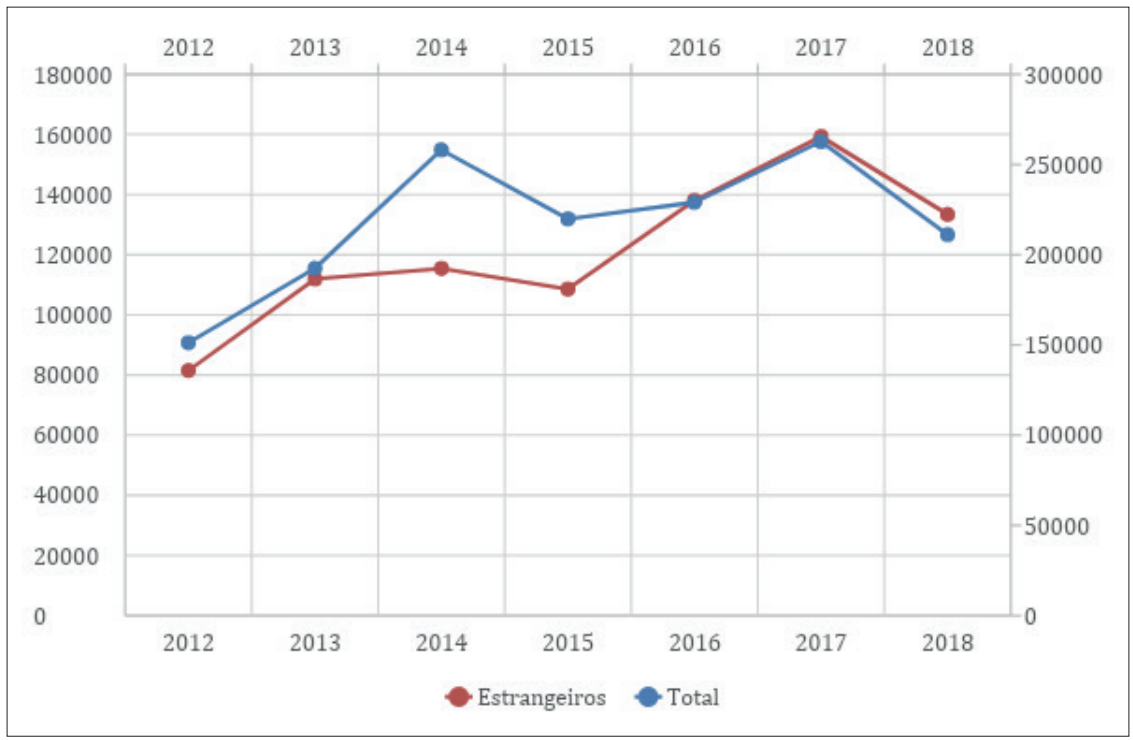

Fonte: Instituto Nacional de Estatística (2019) 


\subsection{Visitantes de Grupos Escolares}

Quando se analisa os visitantes de museus que são oriundos de grupos escolares, verifica-se que, no período considerado, a sua evolução foi positiva do ano de 2012 ao ano de 2014. Entre 2014 e 2015 existiu uma quebra acentuada do número de visitantes de grupos escolares, passando de 29304 para 23 609. Desde 2015 até 2017 existiu um aumento progressivo, sendo que o ano de 2017 apresenta o maior número deste tipo de visitantes com 33 796. Em 2018 verifica-se uma inversão do comportamento com diminuição do número de visitantes de museus de grupos escolares (figura 5).

Figura 5: Visitantes de Grupos Escolares dos museus

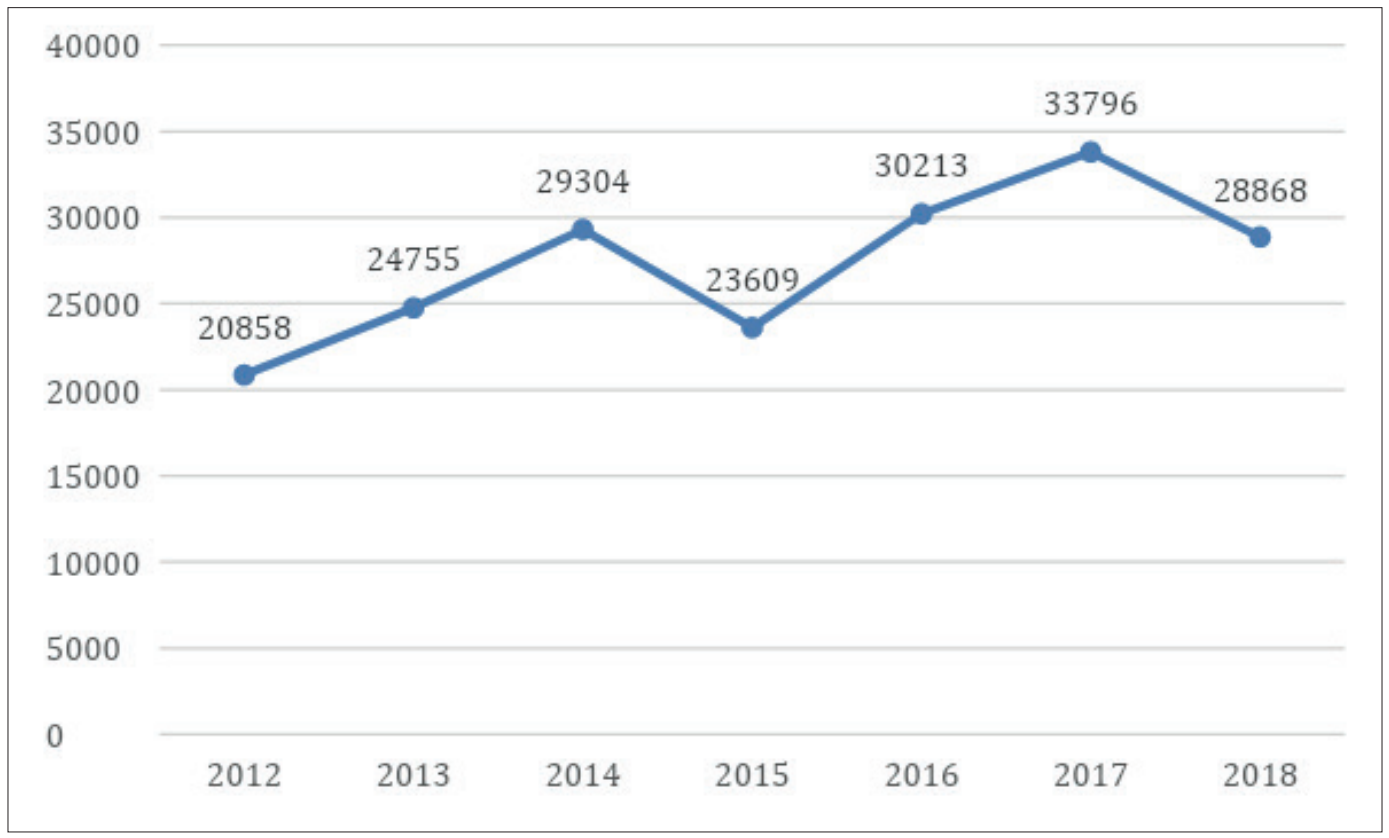

Fonte: Instituto Nacional de Estatística (2019)

\section{Limitações ao estudo}

Este estudo não esgota o tema. O aprofundamento do tema e estudo das diferentes variáveis são necessários. Não podendo concluir que o número de visitantes estrangeiros esteja diretamente relacionado com aumento de turistas, contudo podemos constatar que existe um aumento de ambos indicadores, o que sugere que um possa estar a influenciar positivamente o outro. Sugere-se por isso, que para futuro, se possa aprofundar este estudo, a fim de verificar se existe alguma relação direta entre o número de turistas e o número de visitantes estrangeiros nos museus situados na Região Autónoma da Madeira, e qual o impacto do Turismo nos mesmos, nomeadamente no número de visitantes e na respetiva receita. Outra limitação é existência de alguns dados que são confidenciais, conforme se pode verificar na tabela 3, limitando a análise.

Será igualmente interessante indagar sobre as motivações dos visitantes dos museus e compreender os aspetos que são mais valorizados por estes, para clarificar e melhor direcionar a comunicação com o público visitante.

Pelo de facto de provavelmente alguns espaços contabilizados estatisticamente, corresponderem por hipótese a centros culturais ou interpretativos ou a sítios de interesse patrimonial, mas não musealizado, importará considerar e verificar se os critérios de elegibilidade da amostra se correspondem ou não à definição e tipologia de museus, inscrita na Lei-quadro ou pelo ICOM e se os mesmos integram a rede portuguesa de museus. 
Do mesmo modo, é de suma importância a disponibilização e organização de dados por subsecções tutelares (públicas regionais, municipais e privados) e diferenciando as diferentes tipologias de museus, de outros espaços culturais, monumentos e sítios, a fim de melhor esclarecer a investigação científica.

\section{Discussão/Conclusão}

Na generalidade, o setor museológico tem evoluído a nível nacional, tendo a RAM vindo acompanhar esta evolução. Contudo, notamos que a realidade museológica, da RAM, está condicionada ou fortemente exposta ao setor do Turismo, determinada pela acentuada proporção de número de visitantes estrangeiros. Entre 2017 e 2018, as estatísticas oficiais, constatam um decréscimo do número de visitantes em museus nos quais uma grande maioria são estrangeiros. Importa continuar a ativar mecanismos de captação de novos públicos locais, envolvendo-os desde a génese das coleções ou da produção artística (Goes, 2020).

Apesar da nota que acompanha a estatística justificar "a quebra acentuada no número de visitantes" dever-se "fundamentalmente ao encerramento temporário do Museu da Quinta das Cruzes", importa realçar o porquê de os números globais de visitantes não terem sido compensados pela transferência, ou distribuição dos visitantes pela restante oferta museológica no tecido regional. Interessa ainda destacar o facto de o decréscimo do número de visitantes poder apenas se sustentar no facto do encerramento temporário de um museu, quando provavelmente não se apostou no reforço da oferta dos serviços educativos, com grupos escolares e outros públicos regionais. Destaca-se a forte dependência do número de visitantes estrangeiros, que com o devido cuidado poderemos considerá-los como turistas, provavelmente provenientes dos principais mercados emissores e nacionais.

O principal fundamento dos museus, preservação da memória e consciência da civilização, poderá estar subvertido pela distrofia do público visitante. Se o público alvo dos museus, deve ser as comunidades no qual está inserido e tendo como tarefa a sensibilização das futuras gerações - educação não formal - para a história, a arte e a preservação do património, ao subverter uma lógica memorialista, em prol da atratividade turística, estaremos não só a limitar o campo de ação, como a determinar provavelmente a qualidade da oferta e subordinando-a a mecanismos de atração turística.

Ainda mais que num contexto do aumento do investimento público regional e municipal - 2017 para 2018 - nas áreas da Cultura, será de refletir sobre a estranheza dos resultados, manifestamente inferiores, quer no número de visitantes de museus, como já vimos, quer em outros indicadores, nomeadamente na diminuição do número de exposições, podendo servir para outro estudo.

Se a partir de 2017, data dos melhores resultado no turismo na Região Autónoma da Madeira, temos vindo a registar um decrescimento dos fluxos turísticos, até à data, importará refletir para futuro sobre a necessidade de uma estratégia para o sector, na especificidade dos museus, que clarifique, quais os reais propósitos do decisor público, para a existência de um museu, e seja consequente com a necessidade de criar mecanismos de atração e promoção junto do seu público alvo: residentes, públicos escolares e turistas.

Este artigo propôs-se a levantar hipóteses e apresentar uma análise dos dados estatísticos disponíveis correlacionando-os. Existiu uma impossibilidade de estabelecer uma relação direta e objetiva com base nos dados disponíveis e pela amostra estatística e pelo facto de não ter sido realizado outro estudo específico sobre o efeito.

Se é certo que importa trabalhar conjuntamente, diversificando os públicos e contribuir para um conhecimento universal, e para a sua partilha no contexto global, importa que, sem pretender uma sedução do espetador, se determine a oferta museológica à promoção turística e por conseguinte ao modo como esta oferta é "vendida" ou apresentada no exterior. De acordo com Goes (2020), "Tenhamos a capacidade de acrescentar à memória e assim atualizarmos o discurso estético, conferindo-lhe uma dimensão global e só assim deste modo, talvez consigamos preservá-lo”. Urge aprofundar as relações com as populações locais, que habitam o território onde estão inseridos os museus e abri-los à comunidade e verdadeiramente democratizar o acesso à Cultura".

Observa-se que o "público visitante" não pode ser analisado como um sujeito coletivo uniforme, nem como um corpo pluridisciplinar provido de uma pele plurilinguística ou de acesso a informação única, mas sim, tendo em conta cada que sujeito-espectador tem uma especificidade cultural e geográfica própria, valorizando o carácter humano da mesma, nas suas diferentes motivações, interesses e expectativas (Davis \& Verlag, 2018).

A recolha e disponibilização dos dados, enquanto segmentados em grandes grupos heterogéneos, poderá não ser suficiente para estudos mais aprofundados. 
Os Museus na Região Autónoma da Madeira, à semelhança dos situados em território continental, em espaço nacional, são:

“(...) fortemente condicionados (...) um tardio e incipiente desenvolvimento da ciência e indústria nacionais, que entravou a constituição de instituições museológicas durante um longo período de tempo, e a permeabilidade à influência das tendências europeias e internacionais (...).” (Delicado, 2006).

Apesar do aumento do número de museus desde há várias épocas e ao progressivo crescimento do número de visitantes, a frequência destes espaços fica aquém das expectativas e do potencial económico gerado, distando dos seus congéneres a nível nacional e internacional. Na Madeira, como no caso nacional, "... face às baixas taxas de frequência pelo público destes equipamentos, ficam por aferir os reais impactos sociais que este forte investimento na promoção da cultura científica tem provocado" (Delicado, 2006).

Em anteriores estudos, apontava-se que "a população madeirense continuava pouco sensibilizada para a arte e para a cultura, sendo que os museus continuavam a ser visitados, preferencialmente, por turistas, que constituíam cerca de $98 \%$ de visitantes" (Silva, 2003). Volvida mais de uma década, através dos dados disponibilizados pelo presente estudo, foi possível constatar um crescimento da atividade na RAM, sendo que em 2018, apresentou um número global de 211171 visitantes (figura 2). Já em relação aos visitantes estrangeiros - que podem não representar o universo dos turistas nos museus - segundo o Instituto Nacional de Estatística - representavam em 2018, 63\% do universo de visitantes (figura 4).

Verifica-se que o aumento de visitantes nos museus da RAM, está influenciado pelo aumento dos visitantes estrangeiros na Madeira, mas não só, pois a sua proporção diminui de $98 \%$ no ano 2000 (Silva, 2003) para 63\% no ano 2018.

Não obstante o notório aumento de visitantes, é necessário equacionar o aumento da oferta museológica disponível. No entanto, permanecem as mesmas dificuldades na captação de novos públicos, ficando aquém do potencial social, cultural e económico gerado em torno dos museus.

Potenciar o aumento de públicos para os museus somente será possível com uma operação contínua de experiências pessoais diferenciadas e de uma programação que acompanhe as necessidades de transformação constante e de adequação dos públicos. O trabalho de mediação cultural relacionado com os serviços educativos dos museus, a atualização de informação e digitalização da mesma, a formação contínua de agentes turísticos e guias-intérpretes desempenham um papel fundamental na dotação e transmissão de conhecimento aos espectadores.

A atratividade dos museus, depende da programação, da atualização discursos museográficos e da capacidade de comunicabilidade. No caso da RAM, à semelhança do caso Português, são fatores decisivos para a afluência de mais públicos.

Independentemente da sua execução, está definido no Documento de Orientação Estratégica Regional, (2018), uma estratégia articulada assente em cinco premissas, que propõe minimizar os aspetos negativos supracitados, tendo como horizonte o ano de 2020. Salienta-se os seguintes aspetos: promover a utilização das tecnologias de informação e de comunicação (TIC) como instrumento de um marketing; estimular as parcerias com diversos agentes culturais; incrementar políticas de conservação, investigação, restauro e divulgação; apostar na rentabilização dos conteúdos culturais; fomentar a investigação científica.

A análise dos dados disponíveis permitiu verificar um aumento ainda que pouco acentuado dos visitantes dos grupos escolares, sendo que no ano de 2017 foram 33796 visitantes, o que corresponde à percentagem de $13 \%$ dos visitantes globais, com ligeira inversão no número de visitantes dos grupos escolares em 2018, com um total de 28868 visitantes. A par desta evolução, é possível verificar uma evolução no trabalho, dos serviços educativos e de divulgação que tem sido expressa numa progressiva ligação das instituições à comunidade em que se insere, deduzindo-se uma relação entre estes.

A falta de sensibilização dos madeirenses pela cultura, à imagem dos restantes portugueses, é uma realidade que tenta ser contrariada pelos responsáveis dos museus que começam a tentar encontrar novas formas de persuasão da população procurando desmistificar a ideia de um "Museu fechado" exclusivo de uma elite intelectual e turistas (Silva, 2003).

O museu tem na sua missão, como objeto e desígnio, o papel da responsabilidade social, e deste modo deve atuar junto da comunidade em que se insere, possibilitando que esta a reconheça como sua pertença e dele usufrua. É neste contexto que se apresenta como hipótese, o turismo como fator de diálogo, e o estabelecimento de novas relações entre públicos e sinergias entre instituições, entre agentes culturais e económicos, mas sempre envolvendo a comunidade local e os turistas. 
Herreman (2000) citado por (Silva, 2003) "O Turismo é precisamente um dos movimentos mundiais que sacudiu os fundamentos do museu e outras instituições culturais. (...) desenvolveu-se paralelamente ao modelo de consumo da atual sociedade moderna para tornar-se (...) um maior fator económico cultural e social, específico do final do II milénio".

Apesar de o turismo e museus contemplarem diferentes objetivos e metodologias, ambos "são hoje conceitos interdependentes em diversas áreas, existindo, no entanto, diferenças substanciais entre estas práticas, assim como alguns riscos, nomeadamente ao nível da sustentabilidade" (Serra e Carvalho, 2010). Recomenda-se um acompanhamento através de investigação científica, nomeadamente no estudo dos públicos, como acontece nos Museus Nacionais. Pretende-se limitar os impactos negativos do turismo nas opções museológicas e nas práticas de gestão em museus.

Constatou-se, no período em estudo, um aumento do fluxo turístico tendencial até 2017, verificando-se uma quebra em 2018, ficando por demonstrar a relação direta na afluência de visitantes aos museus. Por antítese, os dados disponíveis permitem-nos aferir que a frequência de público escolar [(13,6\% em 2018 do total de visitantes (figura 5)] não interfere com relevância no aumento dos resultados globais de visitantes nos museus no espaço regional, considerando-se por isso que falta potenciar o papel dos serviços educativos e da mediação cultural, nomeadamente junto do público infantojuvenil.

Os museus poderão ser um "instrumento privilegiado de regeneração urbana em cidades históricas", (Silva \& Barranha, 2013). Contudo não se esgotam na pura reabilitação do edificado, mas na necessidade de implementação de práticas discursivas museológicas atualizadas e de uma programação envolvente com a comunidade, que com ela se identifique e por essa razão preserve a identidade do lugar (Moreno-Mendoza et al., 2020). Assim, a preservação da identidade do lugar habitado - museu - poderá permitir a inculturação de hábitos de lazer e desenvolvimento intelectual.

O sucesso de uma relação entre Turismo e Museus, envolvendo as comunidades nos projetos de conceção e programação, trará os ganhos pretendidos para uma sociedade, nomeadamente na Região Autónoma da Madeira, redimensionando-a num contexto Atlântico e global, onde a Cultura muito contribui para o desenvolvimento económico sustentável, o desenvolvimento social e humano, a coesão territorial e para a construção de uma sociedade mais justa, tolerante, inclusiva e solidária.

\section{Bibliografia}

Álvaro Siza Vieira | The Pritzker Architecture Prize. (2020). Retrieved February 17, 2020, from https:// www.pritzkerprize.com/laureates/1992

Associação Comercial e Industrial do Funchal, \& KPMG. (2014). Documento Estratégico para o Turismo na RAM (2015-2020). Retrieved from https://estrategia.turismodeportugal.pt/sites/default/files/ Doc_Estrategico_Turismo_RAM_0.pdf

Barañano. (2008). Métodos e Técnicas de Investigação em Gestão. (Edições Sílabo, Ed.) (1ª Edição). Lisboa: Europress, Lda.

Brandolese, P. (1791). Le cose più notabili di Padova : principalmènte riguardo alle belle arti. Padoa.

Carvalho, P. (2003). Património Cultural e Iniciativas de Desenvolvimento Local no Espaço Rural, (January 2003).

Museu Nacional dos Coches (2020). Retrieved February 17, 2020, from http://museudoscoches.gov.pt/ $\mathrm{pt} / \mathrm{museu} /$

Cruz, F. (2012). Encontro de Estudos Multidisciplinares em Cultura. In A esteticização e a espetacularização da cidade pós-moderna (Vol. 27). Salvador da Bahia.

Davis, C. \& Verlag, T. (2018). Davis, A . and Smeds , K . (Eds .) ( 2016 ). Visiting the Visitor : An Enquiry into the Visitor Business in Museums.

Decreto Legislativo Regional no 15/2017/M da Região Autónoma da Madeira - Assembleia Legislativa. Diário da República n. ${ }^{\circ}$ 109/2017, Série I de 2017-06-06 (2017). Retrieved August 23, 2019, from https://dre.pt/home/-/dre/107477153/details/maximized

Delicado, A. (2006). Os museus e a promoção da cultura científica em Portugal. Sociologia, Problemas e Práticas, 53-72. Retrieved from http://www.scielo.mec.pt/pdf/spp/n51/n51a04.pdf

Direção Regional de Estatística da Madeira (2019). Estatísticas do Turismo da Região Autónoma da Madeira Resultados Definitivos 2018. Direção Regional de Estatística da Madeira, Ed. Retrieved from https://estatistica.madeira.gov.pt/

Frambotto, P. (1656). Note, overo, Memorie del museo di Lodovico Moscardo. Padoa.

Gil, A. (2017). Como Elaborar Projetos de pesquisa. $6^{a}$ edição. São Paulo: E. Atlas, Ed. 
Goes, D. (2019). Cultura em tempos de engate. Retrieved August 26, 2019, from https://jornaleconomico. sapo.pt/noticias/cultura-em-tempos-de-engate- 476177

Goes, D. (2020). Barraca no presépio - O Jornal Económico. Retrieved February 17, 2020, from https:// jornaleconomico.sapo.pt/noticias/barraca-no-presepio-539730

Gonçalves, A. (2009a). As Comunidades Criativas, O Turismo E a Cultura, 11-18.

Gonçalves, A. (2009b). Museus e Turismo: que experiências? - breve reflexão. ICOM Portugal. Retrieved from www.icom-portugal.org

ICOM PORTUGAL (2014). Boletim ICOM Portugal. Série II, n. ${ }^{\circ}$ 1, out. Retrieved from http://icom-portugal.org/multimedia/documentos/201410_BoletimICOMPortugal.pdf

ICOM PORTUGAL (2019). Nova definição de Museu. Retrieved August 22, 2019, from http://icom-portugal.org/2019/08/16/nova-definicao-de-museu/

Instituto de Desenvolvimento Regional, I.-R. (2018). Documento de Orientação Estratégica Regional. Funchal. Retrieved from www.idr.madeira.gov.pt

Instituto Nacional de Estatística (2015). Conta Satélite da Cultura.

Instituto Nacional de Estatística, I. P. (2009). Inquérito aos museus - Documento Metodológico.

International Council of Museums Portugal (2015). Definição: Museu | ICOM Portugal. Retrieved August 12, 2019, from http://icom-portugal.org/2015/03/19/definicao-museu/

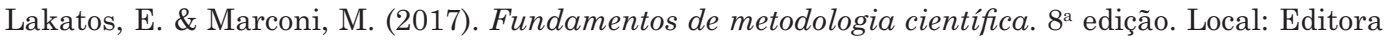
Atlas S. A.

Lei no 47/2004 da Assembleia da República. Diário da República n 195/2004 - Série I-A de 2004-08-19. (2004). Retrieved from https://dre.pt/pesquisa/-/search/480516/details/maximized

Lipovetsky, G. (2019). Ensaio sobre a sociedade da sedução. E. 70, Ed. Lisboa: Pentaedro, Lda.

Madeira, M. da (2020). Plataforma Online - Museus da Madeira. Retrieved February 17, 2020, from https://museus.madeira.gov.pt/Apresentacao

Marques, S. (2014). Museu de Comunidade e Experiência Turística Cultural e Criativa: o caso do Museu Agrícola de Riachos. Instituto Politécnico de Tomar.

Mello, A. (2019). Mercados em Números - Portugal. Mercados em Números. Lisboa. Retrieved from https://travelbi.turismodeportugal.pt/pt-pt/Documents/Mercados/Portugal/portugal-mercado-em-numeros-agosto-2019.pdf

Monge, M. (2018). Lei Quadros dos Museus e Descentralização. Que caminhos? Boletim ICOM Portugal, Série III, n. ${ }^{\circ}$ 11. Retrieved from https://issuu.com/icomportugal/docs/boletim_icom_portugal_11_fev_2018

Morais, I. A. de L. (2013). Quem são os turistas culturais dos museus? PASOS Revista de Turismo y Patrimonio Cultural, 11(1), 29-43. https://doi.org/10.25145/j.pasos.2013.11.001

Moreno-Mendoza, H., Santana-Talavera, A. \& Boza-Chirino, J. (2020). Perception of governance, value and satisfaction in museums from the point of view of visitors. Preservation-use and management model. Journal of Cultural Heritage, 41, 178-187. https://doi.org/10.1016/j.culher.2019.06.007

Museu de Arte, A. e T. (2020). Sobre | MAAT. Retrieved February 17, 2020, from https://www.maat.pt/ pt/art and architecture museum in lisbon

Neves, J. S., Santos, J. A. dos \& Nunes, J. S. (2008). Os museus em Portugal: políticas públicas e dinâmicas do sector em Portugal nos anos mais recentes. VI Congresso Português de Sociologia. Retrieved from http://historico.aps.pt/vicongresso/pdfs/768.pdf

Paulo Mendes da Rocha I The Pritzker Architecture Prize. (2020). Retrieved February 17, 2020, from https://www.pritzkerprize.com/laureates/2006

Ponzini, D., Ruoppila, S. \& Jones, Z. M. (2019). What difference does democratic local governance make? Guggenheim museum initiatives in Abu Dhabi and Helsinki. Environment and Planning C: Politics and Space, O(0), 1-19. https://doi.org/10.1177/2399654419857096

Portugal, I. (2018). Boletim ICOM Portugal. Série III Fevereiro $2018 N^{\circ}$ 11, 72. Retrieved from http:// icom-portugal.org/wp-content/uploads/2018/02/Boletim_ICOMPT_11_Fev_2018_site.pdf

Prodanov, C. C. \& Freitas, E. C. de. (2013). Metodologia do Trabalho Científico: Métodos e Técnicas de Pesquisa e do Trabalho Acadêmico. Universidade FEEVALE. https://doi.org/10.1017/ CBO9781107415324.004

Queiró, J. (2017). O Ensino Superior em Portugal. (F. F. M. dos Santos, Ed.) (1ª Edição). Lisboa.

Raposo, L. (2010). Uma viagem aos museus com paragem prolongada no Museu Nacional de Arqueologia. Retrieved August 28, 2019, from http://home.fa.utl.pt/ jaguiar/MIARQ/Luis RaposoAula3MIARQ.pdf Raposo, L. (2016). Boom turístico, estatísticas e museus. Ípsilon. 
Resolução do Conselho de Ministros da Presidência do Conselho de Ministros. Diário da República n. ${ }^{\circ}$ 94/2008, Série I de 2008-05-15. Retrieved February 13, 2020, from https://dre.pt/web/guest/pesquisa/-I search/249206/details/maximized

Santos, A. (2015). O Pincel é uma Arma. (Âncora, Ed.) (1ª edição). Porto.

Schlosser, J. \& Falguières, P. (2012). Les Cabinets d'Art et de Merveilles de la Renaissance Tardive: Une Contribuition à l'Histoire du Collectionnisme. (1st ed.). Paris: Éditions Macula.

Secretaria Regional da Economia Turismo e Cultura. (2016). Estratégia para o Turismo da Madeira 2017-2021. Secretaria Regional da Economia Turismo e Cultura.

Serra, P. \& Carvalho, P. (2010). Museus e Turismo. Dois casos de estudo (Caldas da Rainha e Óbidos) na Região Oeste de Portugal. In Investigação e Desenvolvimento Sócio-Cultural (actas).

Silva, R. \& Barranha, H. (2013). Museus na cidade: lisboa como exemplo. In Encontro Internacional Arquimemória.

Silva, S. (2003). Realidade Museológica no Arquipélago da Madeira - da génese à actualidade. Lusófona.

Thörn, C. (2011). Spotcity: a arte e a política do espaço público. Forum Sociológico, (21), 43-53. https:// doi.org/10.4000/sociologico.435

Turismo de Portugal. (2019). Estratégia Turismo 2027 Liderar o Turismo do futuro. Retrieved from https://www.turismodeportugal.pt/SiteCollectionDocuments/estrategia/estrategia-turismo-2027.pdf 